\title{
Neuropharmacological Evaluation and HPTLC Fingerprint Profile of Phytocompound-Enriched Chloroform Fraction of Methanolic Extract of Lagenaria Siceraria (Molina) Standley Fruits - a Potent Asian Ethno-Medicinal Vegetable Plant
}

\author{
Sachin Parmar ${ }^{1}$, Rakesh Prajapati ${ }^{2}$, Manisha Kalarias ${ }^{3}$ \\ ${ }^{1}$ Department of Pharmaceutical Sciences, Saurashtra University, Rajkot, India \\ ${ }^{2}$ Department of Pharmacognosy, Bhagwan Mahavir College of Pharmacy, Surat, India \\ ${ }^{3}$ Department of Pharmacognosy, B. K. Mody Govt. Pharmacy College, Rajkot, India
}

Corresponding author: Sachin Parmar, Department of Pharmaceutical Sciences, Saurashtra University, Rajkot, India; E-mail: parmarsachin@rediffmail.com

Received: 9 Oct 2020 Accepted: 13 Jan 2021 Published: 28 Feb 2022

Citation: Parmar S, Prajapati R, Kalaria M. Neuropharmacological evaluation and HPTLC fingerprint profile of phytocompoundenriched chloroform fraction of methanolic extract of Lagenaria siceraria (Molina) Standley fruits - a potent Asian ethno-medicinal vegetable plant. Folia Med (Plovdiv) 2022;64(1):84-95. doi: 10.3897/folmed.64.e59492.

\begin{abstract}
Introduction: Lagenaria siceraria (Molina) Standley (Cucurbitaceae) is a traditional vegetable plant, popularly known as bottle gourd (English) and lauki (Hindi). It is a climbing herb characterized with a number of therapeutic properties. Traditionally Lagenaria siceraria (LS) fruits were used for their cardioprotective, hepatoprotective, diuretic, and purgative effects, but there is very little scientific data available on its neuroprotective potential.
\end{abstract}

Aims: The present study aimed to assess the neuropharmacological profile of the sterol-enriched chloroform fraction of methanolic extract of Lagenaria siceraria fruits in animal experimental models.

Materials and methods: Neuropharmacological screening was conducted in specific reported animal models. Adult Wistar albino rats were subjected to behaviour despair test and elevated plus maze test. Thiopental-induced sedation, locomotor activity, and rota rod test were conducted on Swiss albino mice. Similarly, pentylenetetrazole-induced convulsions and maximal electroshock-induced seizures in Swiss albino mice were performed to evaluate the anti-epileptic potential.

Results: The results of the study demonstrated that the anxiolytic activity of phytocompound-enriched chloroform fraction of methanolic extract of Lagenaria siceraria fruits (100,200, and $400 \mathrm{mg} / \mathrm{kg}$ per os) was characterized by increased time spent in and increased number of entries into the open arms of the elevated plus maze prototype as compared to the control group $(p<0.001)$. Chloroform fraction $(100-400 \mathrm{mg} / \mathrm{kg}$, p.o.) showed the dose-dependent significant reduction in duration of immobility $(p<0.001)$ in the behaviour despair test. Similarly, the chloroform fraction was found to exert a significant reduction in motor co-ordination $(p<0.001)$ and prolongation of thiopental-induced sleeping time $(p<0.001)$ during the animal studies. Moreover, the test fraction significantly increased $(p<0.001)$ the onset of myoclonic seizures in pentylenetetrazole-induced convulsions model as well as in the maximal electroshockinduced seizures model at all three dose levels selected. Interestingly, the chloroform fraction neither produced any overt motor dysfunction nor any kind of extra pyramidal symptoms in any of the animal models during pharmacological screening. Preliminary phytochemical screening of the fraction showed presence of saponins, phytosterols, terpenoids, fats, and trace amount of polyphenolic compounds. HPTLC fingerprinting analysis was also carried out.

Copyright by authors. This is an open access article distributed under the terms of the Creative Commons Attribution License (CC-BY 4.0), which permits unrestricted use, distribution, and reproduction in any medium, provided the original author and source are credited. 
Conclusions: This is the first study exploring the neuroprotective potential of Lagenaria siceraria fruits by showing the anxiolytic, anti-depressant, sedative, and anti-epileptic-like activities, confirming the traditional claims. Future prospectus and investigations will give emphasis on isolation of the bioactive phytocompounds and their precise mechanisms involved in the neuroprotective activities.

\section{Keywords}

behaviour despair test, elevated plus maze test, maximal electroshock-induced seizures, pentylenetetrazole-induced convulsions, phytochemical screening, rota rod test, thiopental-induced sedation

\begin{tabular}{|c|c|}
\hline \multicolumn{2}{|l|}{ Abbreviations: } \\
\hline Ach: acetyl chlorine; & LS: Lagenaria Siceraria; \\
\hline $\begin{array}{l}\text { CFMLS: chloroform fraction of the methanolic extract of Lage- } \\
\text { naria Siceraria fruits; }\end{array}$ & MES: maximal electroshock-induced seizures; \\
\hline EPM: elevated plus maze; & NMDA: N-methyl D-aspartate; \\
\hline GABA: gamma amino butyric acid; & SCMC: sodium carboxy methyl cellulose; \\
\hline HLTE: hind limb tonic extension; & WHO: World Health Organization; \\
\hline IAEC: Institutional Animal Ethics Committee; & PTZ: pentylenetetrazole \\
\hline
\end{tabular}

\section{INTRODUCTION}

In recent time, the prevalence of various neuropsychological and psychosomatic disorders such as depression, anxiety, epilepsy, stress, etc., has been found to be increasing among humans due to striving lifestyle, urbanization, hectic work schedule, and stressful environment. According to a report of World Health Organization (WHO), neurological disorders are likely to become the second leading cause of death worldwide by the end of the 21st century. ${ }^{1}$ Although there are many effective anxiolytic and antidepressant medicines available today, the therapy is still inadequate with unsatisfactory results in almost one-third of all the patients treated. Approximately $60 \%$ of the anxious or depressed patients respond to the currently available allopathic treatments, but the magnitude of improvement is still disappointing. ${ }^{2}$ Therefore, it is of utmost necessity that we find and develop some newer, safer, and more effective neuroprotective phytochemicals from the traditional herbs. ${ }^{3}$

Traditional herbs have played a crucial role in the management of neurological disorders. Therefore, the alternative therapies including herbal and complementary medicines have become very popular today. Lagenaria siceraria (Molina) Standley (LS) syn. L. leucantha Rusby (Family: Cucurbitaceae) is a well-known traditional ethnomedicinal vegetable plant in Asian countries. It is a wealthy source of therapeutically active phytoconstituents and necessary nutrients, which are needed for health benefits. ${ }^{4}$ Traditionally, LS fruits were widely used for their cardioprotective, hepatoprotective, diuretic, purgative, and aphrodisiac properties. ${ }^{5,6}$ They are very effective in curing bronchitis, pain, ulcers, fever, cough, leucorrhoea, vaginal, and uterine disorders. ${ }^{5}$ Phytochemical studies suggest that LS fruits contain therapeutically potent group of phytoconstituents, like flavonoids, polyphenols, terpenoids, saponins, and tannins..$^{7-9}$ They are also found to have vital nutrients like vitamin $\mathrm{C}$, vitamin $\mathrm{B}$-complex, $\beta$-carotene, pectin, choline, dietary fibers, proteins, palmitic acid, stearic acid, and oleic acid.

According to traditional literature, LS fruits are used as nerve tonics. But until today, few investigations have been carried out to evaluate their effects on nervous disorders.

\section{AIM}

With this background, the present study was aimed at evaluating the detailed neuropharmacological profile of LS fruits by using suitable animal experimental models.

\section{MATERIALS AND METHODS}

\section{Collection and authentication of plant material}

Fresh LS fruits were purchased from the local market of Surat, Gujarat, India. Further, the plant was identified and authenticated by Dr. Sumita Dasgupta, Dept. of Botany, Bhagwan Mahavir College of Science \& Technology, Surat, Gujarat, India. A specimen voucher (SU/DPS/Herb/05) of the plant has been deposited and maintained at the Herbal Museum, Department of Pharmaceutical Sciences, Saurashtra University, Rajkot, India for future reference. 


\section{Extraction of plant material}

LS fruits were properly washed and cleaned. They were cut into thin round slices and then dried by shade drying. The dried slices were ground into coarse powder. Then the coarsely powdered dried fruits of LS ( $20 \mathrm{~g})$ were subjected to Soxhlet extraction for 5 hours by using solvent methanol. After the extraction procedure, the supernatant was collected and concentrated in vacuo to yield a brown-colored sticky concentrate. This concentrate was preserved at a freezing temperature $\left(4^{\circ} \mathrm{C}\right)$ for further studies.

\section{Fractionation of the crude extract}

The crude methanolic extract of LS was suspended in 250 $\mathrm{ml}$ of distilled water in a separating funnel and partitioned successively with the solvents, i.e., petroleum ether, chloroform, acetone, and $\mathrm{n}$-butanol ( $250 \mathrm{ml}$ each) to obtain fractions. All the fractions were collected, concentrated, and preserved at $4^{\circ} \mathrm{C}$ throughout the study.

\section{Preliminary phytochemical screening}

All the fractions were screened through qualitative phytochemical tests for determination of the various phytoconstituents. ${ }^{10}$

\section{Qualitative determination and identification of sterols}

Sterols were detected more accurately by performing the following confirmatory phytochemical tests. ${ }^{11}$ The test solution was prepared by boiling about $50 \mathrm{mg}$ of chloroform fraction of methanolic extract of LS fruits (CFMLS) in $50 \mathrm{ml}$ of distilled water for $5 \mathrm{~min}$ and then filtered to obtain the clear test solution.

Salkowski reaction: To the test solution, a few drops of concentrated sulphuric acid were added, and the colour change was observed.

Liebermann-Burchard reaction: To the test solution, a few drops of concentrated sulphuric acid and 2-3 drops of acetic anhydride were added, and further the change in colour was observed.

\section{Experimental animals}

Adult Swiss female albino mice (body wt.: 25-30 g) were grouped $(\mathrm{n}=6)$ and kept under typical conditions (temperature: $25-27^{\circ} \mathrm{C}$; relative humidity: $55-65 \%$, and a 12 -hr lightdark cycle). Experimental mice were fed standard rodent chow (purchased from Pranav Agro Sales, Ahmedabad, Gujarat, India) and water ad libitum. Mice were acclimatized to laboratory environmental conditions for at least 8 to 10 days prior to experiments. All the experiments were conducted in a noise-free laboratory compartment during the light phase (between 08:00 and 16:00 hours) and the mice were not fasted prior to drug treatments. The animal trials were approved by the Institutional Animal Ethics Committee (IAEC), Constituted for the Purpose of Control and Supervision of Experimental Animals (CPCSEA) by Ministry of Environment and Forests, Government of India, New Delhi (Protocol approval No. 1521/ac/07/CPCSEA).

\section{Drugs and chemicals}

Pentylenetetrazole (PTZ), diazepam, chlorpromazine, and phenytoin sodium were purchased from Sigma (USA). The solvents used in the study were of analytical grade. Fluoxetine and imipramine were procured as gift samples for Torrent Pharmaceuticals, Ahmedabad, India.

\section{Preparation of drug samples and treatments}

All the reference standard drugs and CFMLS were suspended in $1 \%$ w/v Sodium Carboxy Methyl Cellulose (SCMC) in distilled water and administered via p.o. route at selected dose levels of 100,200 , and $400 \mathrm{mg} / \mathrm{kg}$ of body weight of animal. The control group of animals received only the vehicle ( $1 \% \mathrm{w} / \mathrm{v}$ SCMC). All drug samples were freshly prepared before use and the doses were selected on the basis of acute toxicity studies.

\section{Acute toxicity studies}

As per the OECD guidelines-420, CFMLS was administered orally at doses of $5,50,300,1000$, and $2000 \mathrm{mg} / \mathrm{kg}$ and the animals were examined for occurrence of toxicity symptoms and behavioural changes. The lethal dose was determined according to the guidelines. ${ }^{12}$

\section{Neuropharmacological screening}

\section{Elevated plus maze (EPM) test}

The method of Emamghoreishi et al. was followed. ${ }^{13}$ In brief, the EPM apparatus was wooden and painted black. It consisted of two open arms $(50 \times 10 \mathrm{~cm})$ and two closed arms $(50 \times 10 \times 50 \mathrm{~cm})$, which were extended from a common central platform $(10 \times 10 \mathrm{~cm})$. The entire maze was elevated to a height of $25 \mathrm{~cm}$ above to floor level. Experimental rats were individually placed at the centre of the maze facing an open arm. The number of total entries, and the total time spent in the open as well as in closed arms were recorded over a period of $5 \mathrm{~min}$. Arm entries were recorded when rat enters all its four paws into an arm. The experimental rats were pretreated with diazepam $(5 \mathrm{mg} / \mathrm{kg}$, i.p.) and CFMLS (100, 200, and $400 \mathrm{mg} / \mathrm{kg}$, p.o.), whereas the control group received 1\% SCMC orally. Diazepam $(5 \mathrm{mg} / \mathrm{kg}$, i.p.) was used as standard anxiolytic drug. Between each trial, the maze was wiped and cleaned with a sponge and dried with paper towels to ensure uniform results. 


\section{Spontaneous locomotor activity}

Since the plus maze experiment and sedative effect are affected by the changes in locomotor activity, an additional experiment was carried out with the specific aim to assess the spontaneous locomotor activity by using actophotometer, separately from the elevated plus maze experiment. The actophotometer registered the number of times the infrared photo beams of light were broken, as the rat moved around inside the cage. Each rat was placed in the centre of the metal cage of actophotometer and its locomotor activity was recorded at 5-min intervals for the next 15 minutes. ${ }^{14}$

\section{Behavior despair test}

The procedure described by Porsolt et al. was adapted with slight modification. ${ }^{15}$ Swimming sessions were conducted by placing rats individually in a glass cylinder $(35 \times 25$ $\mathrm{cm})$. In the cylinder, warm water $\left(25 \pm 1^{\circ} \mathrm{C}\right)$ was filled up to the level of $27 \mathrm{~cm}$ from the bottom surface. Two swimming sessions were conducted between 8 o'clock a.m. and 4 oclock p.m. All rats were subjected to an initial 15-min pre-test followed 25 hours later by a 5 -min test. Drugs were administered three times during the study period between these two sessions, first immediately after the pre-test session and then 6 and 23 hours after the first dose. Following both swimming sessions, the rats were removed from the cylinder, dried with paper towels, placed in the cages under a heating source for $15 \mathrm{~min}$, and returned to their home cages. During the experiment the immobility period in seconds was measured in each test session of $5 \mathrm{~min}$. The water in the cylinder was changed after every other trial. Imipramine $(12.5 \mathrm{mg} / \mathrm{kg}$, i.p.) was used as a reference standard drug. ${ }^{16}$

\section{Thiopental-induced sleeping time}

The procedure of Sukma et al. was followed. ${ }^{17}$ In the experiment, $30 \mathrm{~min}$ after the administration of CFMLS (100, 200 , and $400 \mathrm{mg} / \mathrm{kg}$, p.o.) or SCMC (1\%, p.o.), mice received thiopental (50 mg/kg, i.p.). The time elapsed from thiopental injection to loss of the righting reflex was taken as sleeping latency. The time elapsed between the loss and voluntary recovery from the righting reflex was considered as the total sleeping time.

\section{Rotarod performance of mice}

The effect of the fractions on motor coordination activity was measured using a rotarod apparatus (Ambala Cantt, India). Female albino mice were selected and screened primarily at $12 \mathrm{rpm}$ for four consecutive times (an 1-hour interval) for a day. On day 2 , the speed was increased to 24 rpm and the mice that could stay on the rotating rod for 2 or more minutes were selected and grouped into five: three dose levels of the CFMLS fractions $(100,200, \& 400 \mathrm{mg} /$ $\mathrm{kg}$, p.o.); standard group - diazepam $(0.5 \mathrm{mg} / \mathrm{kg}$, i.p. $)$, and a control group as $1 \%$ SCMC (vehicle) treated. On the day of the experiment, each mouse was given a drug-free rotation and $30 \mathrm{~min}$ later treated with the fractions, diazepam, or $1 \%$ SCMC, and tested at every 30 minutes for 2 hours.
The latency to fall was recorded as the time spent on the rotating rod. ${ }^{18}$

\section{Pentylenetetrazole (PTZ)-induced convul- sions in mice}

To evaluate the anticonvulsant effect, the method described by Fisher RS was adapted. ${ }^{19}$ In brief, clonic seizures were induced in drug/vehicle pretreated albino mice (25-50 g) by an intraperitoneal injection of $100 \mathrm{mg} / \mathrm{kg}$ of PTZ. The animals were pretreated with CFMLS \& CFMLS (100, 200, and $400 \mathrm{mg} / \mathrm{kg}$, p.o.) thirty minutes before the injection of PTZ. The control animals received $0.1 \%$ SCMC solution. After the PTZ injection, the animals were placed in separate transparent Plexiglas cages $(25 \times 15 \times 10 \mathrm{~cm})$. The latencies to myoclonic seizures were observed over a $30-\mathrm{min}$ period. The ability of tested drug to prevent the seizures was considered as indication of its anticonvulsant action.

\section{Maximal electroshock-induced seizures (MES) in mice}

Electro-convulsive shock, inducing hind limb tonic extension (HLTE) in 99\% of the animals was determined by a current intensity-percent effect curve. The electrical stimulus $(50 \mathrm{~mA}, 50 \mathrm{~Hz}, 1 \mathrm{sec}$ duration) was applied through ear-clip electrodes using a stimulator apparatus (Ambala Cantt., India). Five groups of 6 mice (25-50 g) each were pretreated with CFMLS (100, 200, and $400 \mathrm{mg} / \mathrm{kg}$, p.o.); phenytoin (25 mg/kg, i.p, as positive control); $1 \%$ SCMC (i.p.) $(10 \mathrm{ml} / \mathrm{kg}$, as control). After 30 minutes, the animals received transauricular electroshock. The criterion for the anticonvulsant effect was onset of HLTE (absence of HLTE within $10 \mathrm{sec}$ ) after delivery of the electroshock. ${ }^{20}$

\section{HPTLC fingerprinting analysis}

Nowadays, HPTLC Fingerprint Profiling is believed to be a unique tool for identification and qualitative evaluation of medicinal herbs and herbal formulations. ${ }^{21}$ The CAMAG HPTLC instrument is composed of automated Linomat 5 TLC applicator, having a $100 \mu \mathrm{l}$ syringe connected to a nitrogen cylinder providing a delivery speed of $150 \mathrm{nl} / \mathrm{sec}$, twin-trough developing chamber, and WinCATS scanner (Camag, Muttenz, Switzerland). $0.2 \mathrm{~mm}$ thickness containing pre-coated TLC plates of aluminum backed silica gel 60 F 254 was used. The mobile phase used was toluene: ethyl acetate $(7: 3)$ for the separation of the phytocompounds from CFMLS. The plate was developed horizontally in a Camag horizontal developing chamber $(10 \times 5 \mathrm{~cm})$ at a room temperature. The plate was scanned at different wavelengths such as $254 \mathrm{~nm}$ and $366 \mathrm{~nm}$ with the help of Camag TLC scanner III using the WinCATS Planar chromatography manager 1.2.3 software.

\section{Statistical analysis}

All data were expressed as mean $\pm \operatorname{SEM}(n=6)$ and analyzed by one-way analysis of variance (ANOVA), followed by the 
Student Newman-Keuls test. The groups treated with CFMLS and standard drugs were compared with the respective control (vehicle) groups. $P$ values $<0.001$ were considered statistically significant.

\section{RESULTS}

\section{Fractionation of the crude extract}

A total of 4 fractions were prepared and tested further for their total yield and organoleptic characters. The obtained results suggest that the chloroform and acetone fractions exhibited high extractive yields among all the fractions (Table 1).

\section{Preliminary phytochemical screening}

The results of phytochemical screening showed that CFMLS elicited the presence of phytosterols, saponins, terpenoids, phenolic compounds, and flavonoids as major classes of phytocompounds, which were desirable to exert neuroprotective action (Table 2).

\section{Qualitative determination and identification of sterols}

Salkowski reaction: Addition of a few drops of concentrated sulphuric acid formed a reddish colour in the test solution indicating the presence of steroidal nucleus.

Liebermann-Burchard reaction: Addition of a few drops of concentrated sulphuric acid followed by the addition of 2-3 drops of acetic anhydride, the test solution turned to violet blue and finally formed green colour which indicated the presence of sterols.

\section{Acute toxicity studies}

From the results of acute toxicity studies, the $\mathrm{LD}_{50}$ value of CFMLS was determined as $1000 \mathrm{mg} / \mathrm{kg}$; p.o. route in mice. Therefore, three dose levels 100, 200, and $400 \mathrm{mg} /$ $\mathrm{kg}$, p.o. body weight., corresponding to 10,20 , and $40 \%$ of the $\mathrm{LD}_{50}$ value $(1000 \mathrm{mg} / \mathrm{kg}$, p.o.) were selected to perform neuropharmacological investigations. There was no death or any kind of toxicity symptoms like diarrhoea, tremors, or unconsciousness, observed in mice at the selected doses. Moreover, there were no changes detected in eyes, skin colour, fur, or mucous membranes of the experimental mice during the study.

Table 1. Results of organoleptic and qualitative evaluation of various fractions of methanolic extract of $L$. Siceraria fruits

\begin{tabular}{lllll}
\hline Sr. No. & Fraction & Colour & Consistency & Yield (\%) \\
\hline 1 & Pet. ether & Light hazy yellow & Sticky & 1.72 \\
2 & Chloroform & Dull brown & Non sticky & 3.35 \\
3 & Acetone & Brown & Sticky & 9.46 \\
4 & n-Butanol & Brown & Sticky & 3.72 \\
\hline
\end{tabular}

Table 2. Results of phytochemical screening of methanolic extract of $L$. Siceraria fruits and their fractions

\begin{tabular}{|c|c|c|c|c|c|}
\hline Sr. No. & Test & $\begin{array}{l}\text { Pet. } \\
\text { Ether }\end{array}$ & Chloroform & Acetone & n-butanol \\
\hline 1 & Alkaloids & - & - & - & - \\
\hline 2 & Carbohydrates & - & - & + & + \\
\hline 3 & Phytosterols & + & + & - & - \\
\hline 4 & Fixed oils and fats & + & + & + & - \\
\hline 5 & Saponins & - & + & + & - \\
\hline 6 & Terpenoids & - & + & - & - \\
\hline 7 & Phenolic comp. \& tannins & - & - & + & + \\
\hline 8 & Proteins \& amino acids & - & - & - & + \\
\hline 9 & Gums and mucilage & - & - & - & - \\
\hline 10 & Volatile oil & - & - & - & - \\
\hline 11 & Flavonoids & - & + & + & + \\
\hline
\end{tabular}

+ present; - absent 


\section{Results of neuropharmacological screening}

\section{Elevated plus maze test on rats}

The control animals showed more preference for the closed (dark) arms and exhibited anxiety-like symptoms characterized by immobility, freezing, and defecation on entering the open arms. As compared to the control group, the CFMLS-treated animals (100, 200, and $400 \mathrm{mg} / \mathrm{kg}$, p.o.) showed significant increase in the time spent $(p<0.001)$ in the open arms (Fig. 1a) and total number of entries $(p<0.5 ; p<0.001)$ (Fig. 1b) in a dose-dependent manner. Diazepam $(5 \mathrm{mg} /$ $\mathrm{kg}$, i.p.), a standard drug, significantly increased the number of entries as well as time spent in the open arms $(p<0.001)$, indicating anxiolytic activity. The higher dose of CFMLS (400 mg/kg, p.o.) produced a peak anxiolytic effect that is comparable to that by diazepam $(p<0.001)$ (Figs 1a, 1b).

\section{Behaviour despair test of rats}

Fig. 2 shows the antidepressant effect of CFMLS and imipramine in the experimental animals. The control animals remained immobile for most of the time during the test session. CFMLS (100, 200, and $400 \mathrm{mg} / \mathrm{kg}$, p.o.) induced a dose-dependent significant reduction in the immobility time of rats $(p<0.001)$ as compared to the control group. In the same experimental conditions, the antidepressant activity of the reference standard drug imipramine (12.5 $\mathrm{mg} / \mathrm{kg}$, i.p.) was clearly evident $(p<0.001)$. The antidepressant effect produced by CFMLS $(100,200$, and $400 \mathrm{mg} / \mathrm{kg}$, p.o.) was comparable to that of imipramine.

\section{Thiopental-induced sleeping time in mice}

As shown in Fig. 3, CFMLS (100, 200, and $400 \mathrm{mg} / \mathrm{kg}$, i.p.) showed a significant $(p<0.001)$ dose-dependent prolongation of thiopental-induced sleeping time as compared to the control group. Prior treatment with the standard drug, diazepam (1 mg/kg, i.p.) potentiated significantly the thiopental-provoked sleep $(p<0.001)$.

\section{Spontaneous locomotor activity in mice}

As shown in Fig. 4, CFMLS less effectively exhibited dose-dependent reduction in locomotor activity. Diazepam $(0.5 \mathrm{mg} / \mathrm{kg}$, i.p.) was used as a standard drug, which showed marked reduction in the locomotor activity. However, it can be concluded that CFMLS did not severely affect the locomotor activity of mice after treatment.

\section{Rotarod performance in mice}

Results of the study indicated that CFMLS at the dose of $100 \mathrm{mg} / \mathrm{kg}$ did not show any change in motor coordination. Though at doses of 200 and $400 \mathrm{mg} / \mathrm{kg}$, CFMLS significantly $(p<0.001)$ reduced the time spent on the rotarod at 12 rpm over the 2-hr period as compared to the control group. Diazepam (4 mg/kg, i.p.), a reference standard muscle relaxant drug, produced a significant effect on the skeletal muscle relaxation $(p<0.001)$ (Fig. 5).

\section{Pentylenetetrazole (PTZ)-induced convul- sions in mice}

CFMLS (100, 200, and $400 \mathrm{mg} / \mathrm{kg}$, p.o.) dose-dependently reduced the onset of myoclonic seizures in mice and the reduction was quite significant $(p<0.001)$ as compared to control group. Diazepam, at a dose of $4 \mathrm{mg} / \mathrm{kg}$, i.p., also showed significant reduction $(p<0.001)$ in the occurrence of seizures (Fig. 6).

\section{Maximal electroshock-induced seizures (MES) on mice}

At the entire three dose levels selected, CFMLS significantly $(p<0.001)$ reduced the onset of HLTE in a dose-dependent manner as compared to control group. Phenytoin sodium, at a dose of $25 \mathrm{mg} / \mathrm{kg}$ (i.p.), also showed significant $(p<0.001)$ reduction in the onset of HLTE and occurrence of seizures and provided $100 \%$ protection (Fig. 7).

\section{HPTLC fingerprinting analysis}

HPTLC plate of CFMLS was developed using toluene: ethylacetate $(6: 4, v / v)$ as the mobile phase, followed by TLC scanning at 254 (Fig. 8a) and $366 \mathrm{~nm}$ (Fig. 8b). HPTLC chromatogram of CFMLS (Track 1: $5 \mu$ l concentration) revealed total 8 peaks with $R_{f}$ values within the range of 0.04 to 0.86 . Among them, the peaks with $\mathrm{R}_{\mathrm{f}}$ values $0.04,0.23,0.26$, $0.62,0.66$, and 0.86 were predominant with maximum area percentage $25.22,26.22,7.74,1.37,1.97$, and 15.85 , respectively. Similarly, CFMLS (Track 2: $10 \mu$ concentration) the presence of total 11 compounds with $\mathrm{R}_{\mathrm{f}}$ values ranging from 0.04 to 0.87 , among which the peaks with $R_{f}$ values 0.04 , $0.52,0.64,0.71,0.82$, and 0.90 were observed as principal peaks with area percentage $9.32,53.67,5.19,8.00,9.60$, and 6.07 , respectively. The chromatogram of CFMLS (Track 3: $20 \mu$ concentration) indicated the presence of total 12 peaks with $R_{f}$ values ranging from 0.02 to 0.87 , among which the peaks with $R_{f}$ values $0.04,0.56,0.73$, and 0.93 were observed as principal peaks with area percentage of 11.89, 53.81, 5.60, and 14.55, respectively (Table 3, Fig 9).

\section{DISCUSSION}

In the present study, we investigated the effects of different doses of CFMLS using several neuropharmacological models. EPM is one of the most widely used models for assessment of anxiety. ${ }^{22,23}$ In this model, the anxiety is induced due to natural stimuli, i.e. the fear of a new, brightly-lit open space and balance on a comparatively narrow raised platform. ${ }^{24}$ The entries and the time spent in the open arms is the major index of the anxiety due to the fact that an open area is extremely fearful to rodents. ${ }^{25,26}$ In the present study, CFMLS significantly increased the number of entries and time spent in the open arms in a dose-dependent manner indicating anxiolytic activity. It has been revealed that gamma amino butyric acid (GABA)ergic neurotransmission plays an important role in stress and anxiety associ- 
Time spent in the open arm vs. dose of CFMLS

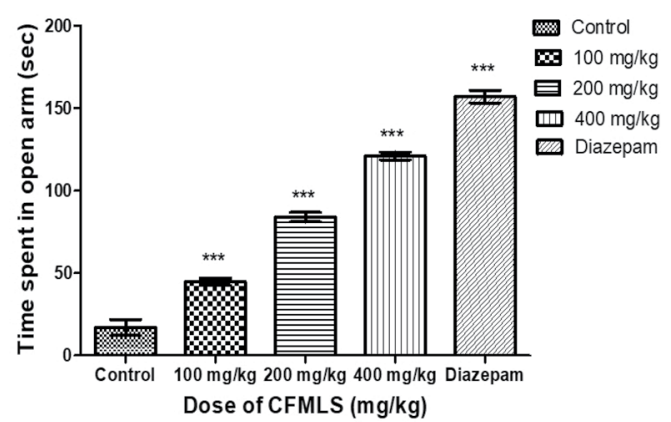

Time spent in the closed arm vs. dose of CFMLS

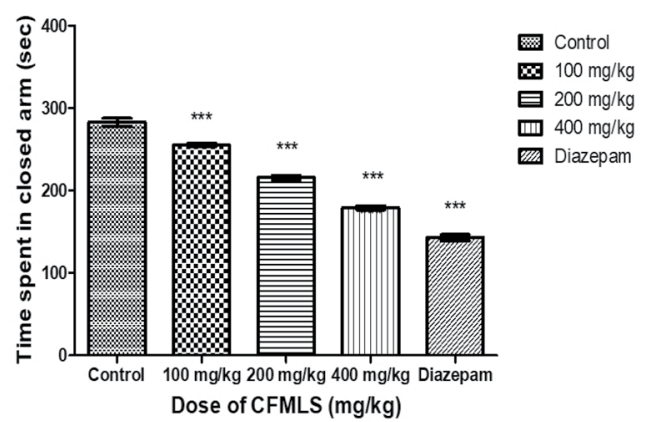

Figure 1a. Effects of chloroform fraction of methanolic extract of L. Siceraria fruits (CFMLS) and diazepam on the time mice spent in the open and closed arms. Values are expressed as mean $\pm \operatorname{SEM}(\mathrm{n}=6) ;{ }^{* *} p<0.01 ;{ }^{* * *} p<0.001$ compared with control (one way ANOVA followed by Student Newman Keuls test).
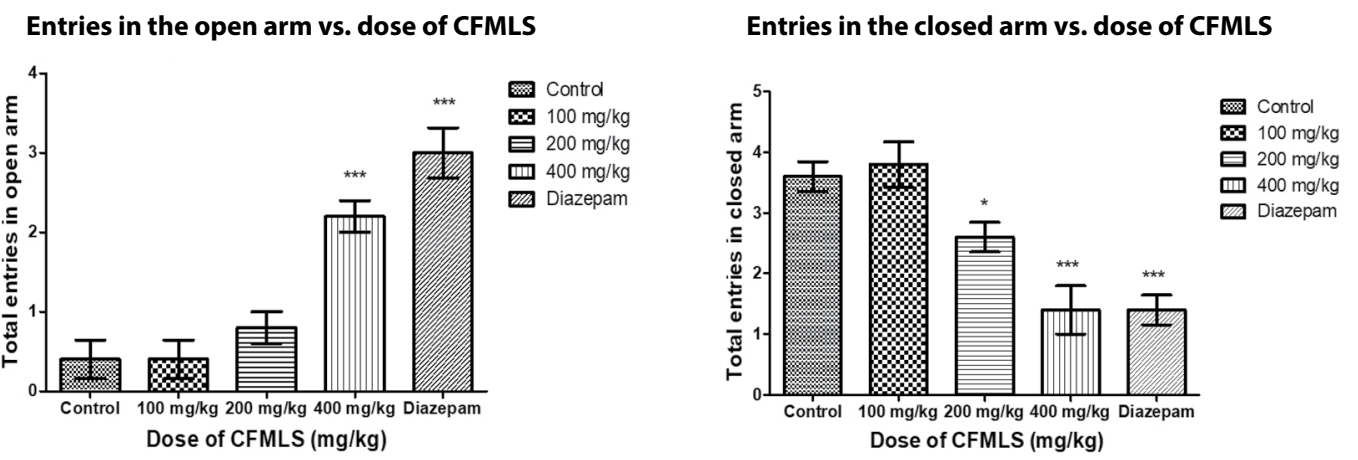

Figure 1b. Effects of chloroform fraction of methanolic extract of L. Siceraria fruits (CFMLS) and diazepam on the number of entries in the open and closed arms by mice. Values are expressed as mean $\pm \operatorname{SEM}(\mathrm{n}=6) ;{ }^{*} p<0.01 ;{ }^{* * *} p<0.001$ compared with controls (one way ANOVA followed by Student Newman Keuls test).

Immobility period vs. dose of CFMLS

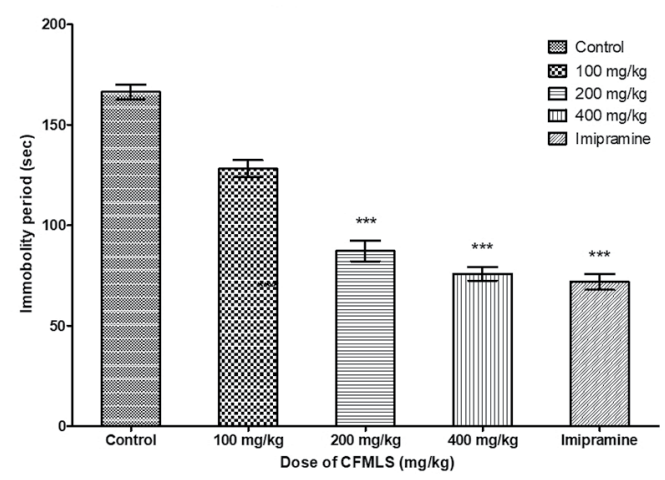

Figure 2. Effects of chloroform fraction of methanolic extract of L. Siceraria fruits (CFMLS) and imipramine on immobility period in mice. Values are expressed as mean $\pm \operatorname{SEM}(n=6) ;{ }^{* *} p<0.001$ compared with control (one way ANOVA followed by Student Newman Keuls test).

ated with elevated plus maze test. ${ }^{27}$ It is likely that CFMLS may have modulated sites of GABA receptors to produce the anxiolytic effect.

The behaviour despair test has been validated as a suitable tool to evaluate the drugs with putative antidepres-
Total sleeping time vs. dose of CFMLS

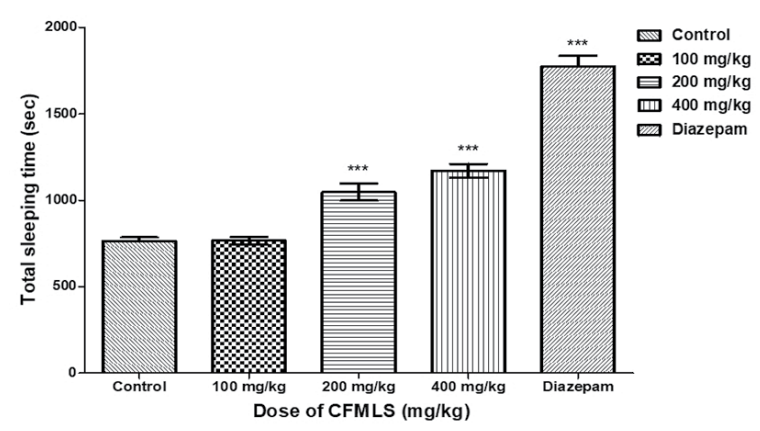

Figure 3. Effects of chloroform fraction of methanolic extract of L. Siceraria fruits (CFMLS) and diazepam on the sleeping time of mice. Values are expressed as mean $\pm \operatorname{SEM}(n=6) ;{ }^{* * *} p<0.001$ compared with control (one way ANOVA followed by Student Newman Keuls test).

sant effects. ${ }^{28}$ In this model, when rodents are forced to swim in a restricted space, they show tendency to become immobile after struggling for a while. This inescapable stressful situation leads to depression. ${ }^{29}$ In the present study, the administration of CFMLS significantly reduced 
Total number of beams crossed vs. dose of CFMLS

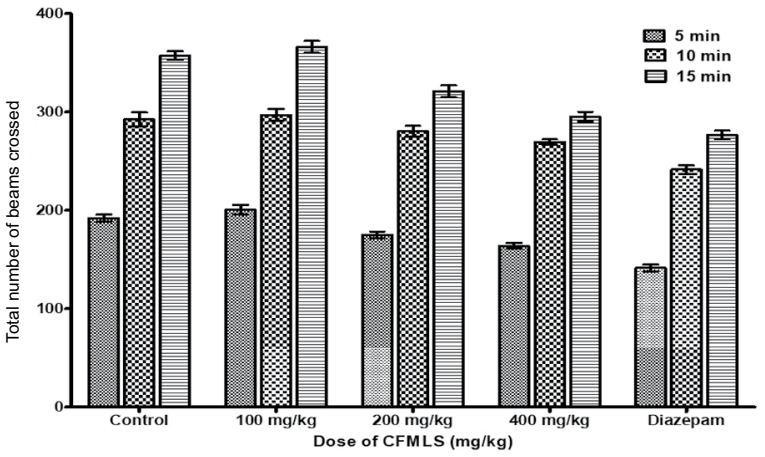

Figure 4. Effects of chloroform fraction of methanolic extract of L. Siceraria fruits (CFMLS) and diazepam on locomotor activity in mice.

\section{Rotarod performance vs. dose of CFMLS}

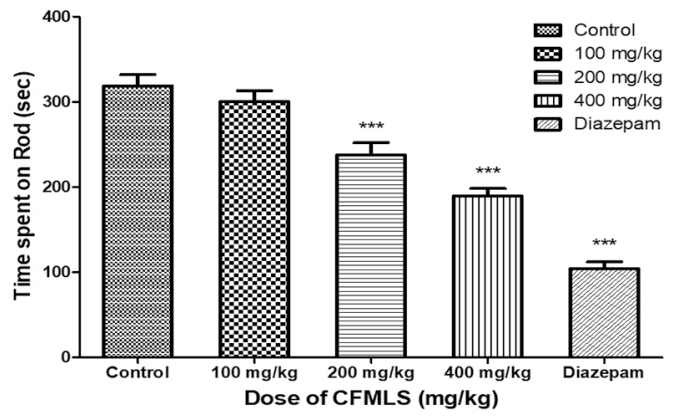

Figure 5. Effects of chloroform fraction of methanolic extract of L. Siceraria fruits (CFMLS) and diazepam on the rota rod performance in mice. Values are expressed as mean \pm SEM $(n=6)$; ${ }^{* *} p<0.01 ;{ }^{* *} p<0.001$ compared with control (one way ANOVA followed by Student Newman Keuls test).

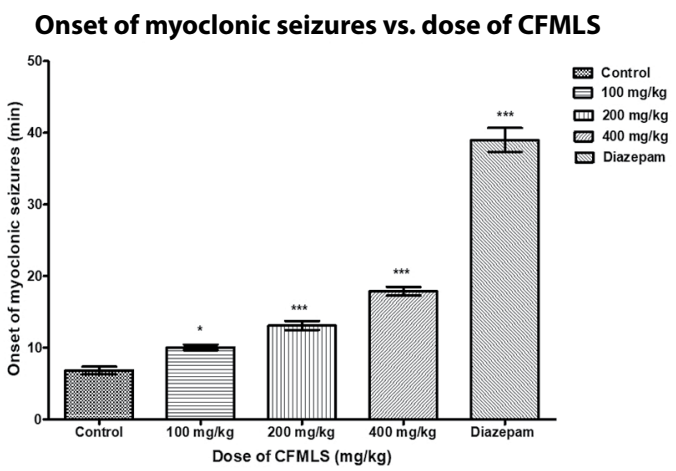

Figure 6. Effects of chloroform fraction of methanolic extract of L. Siceraria fruits (CFMLS) and diazepam on the onset of myoclonic seizures in mice. Values are expressed as mean \pm $\operatorname{SEM}(\mathrm{n}=6) ;{ }^{*} p<0.01 ;{ }^{* * *} p<0.001$ compared with control (one way ANOVA followed by Student Newman Keuls test).

total immobility time and enhanced struggling behaviour in a dose-dependent manner. It is reported that GABA, as an inhibitory neurotransmitter, is directly implicated in the pathophysiology of depression. Moreover, the neurochem-

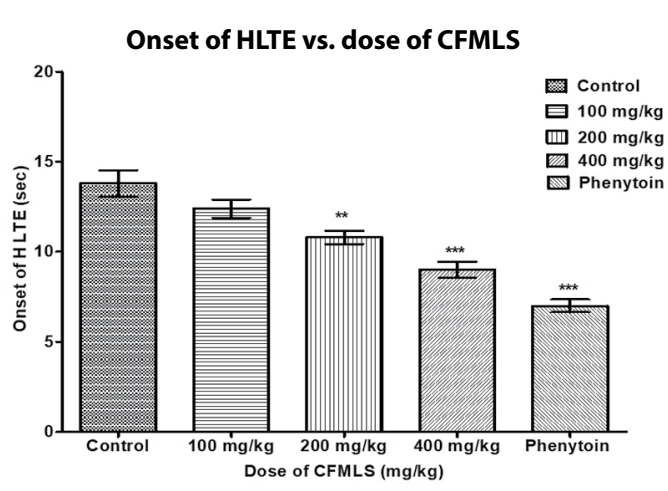

Figure 7. Effects of chloroform fraction of methanolic extract of L. Siceraria fruits (CFMLS) and diazepam on the onset of HLTE in mice. Values are expressed as mean $\pm \operatorname{SEM}(n=6) ;{ }^{* *} p<0.01$; ${ }^{* * *} p<0.001$ compared with control (one way ANOVA followed by Student Newman Keuls test).
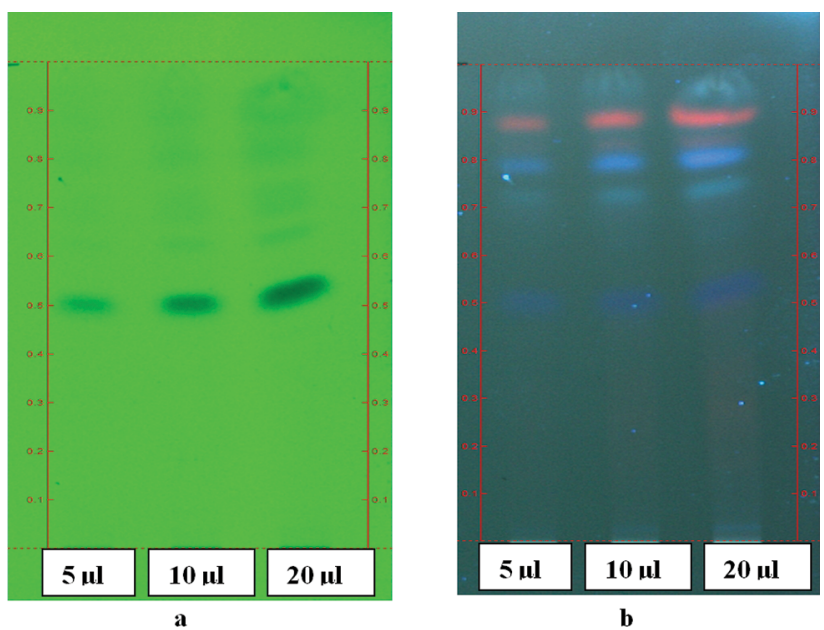

Figure 8. a. High performance thin layer chromatogram of CFMLS at $254 \mathrm{~nm} ; \mathbf{b}$. High performance thin layer chromatogram of CFMLS at $366 \mathrm{~nm}$.

ical studies have revealed that the monoamines (serotonin, noradrenaline, and dopamine) have a crucial role in the development of the depression symptoms. ${ }^{15}$ The antidepressant effect of CFMLS may be attributed to modulate one or more of these neurotransmitters. The serotonergic theory postulates excessive performance of the serotonergic neurotransmission as the cause of depression and anxiety. ${ }^{30}$ Another theory proposes involvement of GABAergic neurotransmission which forms the basis of action of anxiolytic activity of many drugs, may also be involved in the antidepressant activity. ${ }^{31}$ The sterols are reported as neuroprotective antidepressant phytocompounds. ${ }^{31}$ Therefore, it can be hypothesized that the sterols of CFMLS may have acted by modulating one or more of the above mentioned neurotransmitters.

The experiments with thiopental-induced sedation showed that CFMLS significantly reduced the sleep latency and prolonged sleeping time in the test animals. Prolongation of thiopental-induced sleep was an indication of sed- 


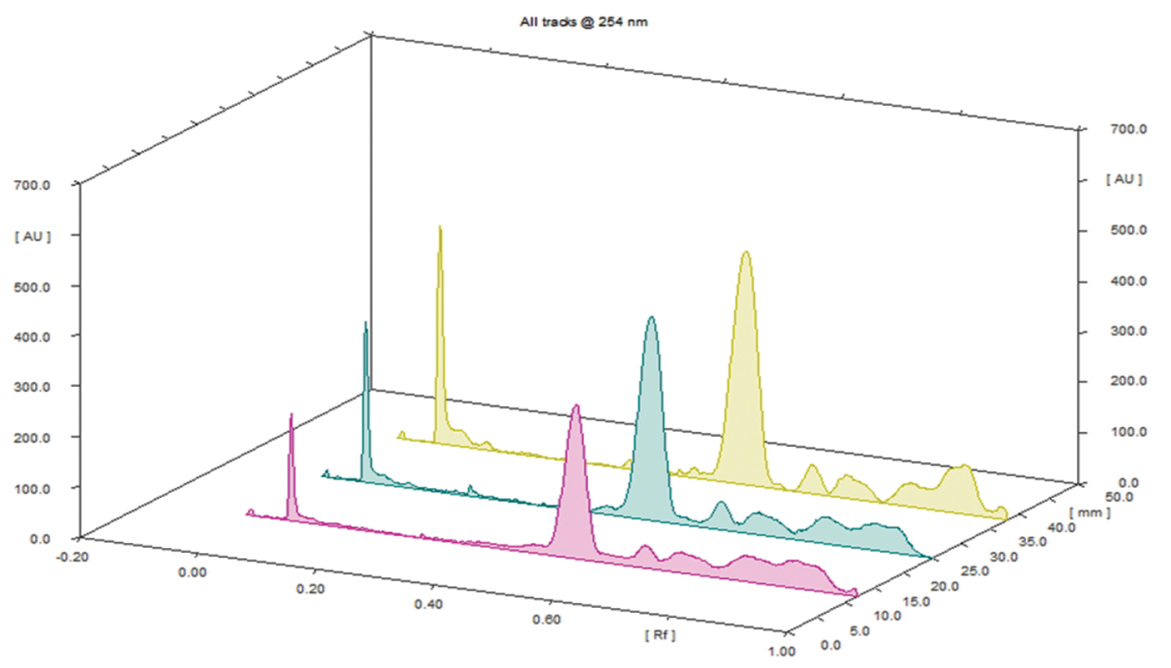

Figure 9. Digital 3D graph of the HPTLC chromatogram of chloroform fraction of methanolic extract of L. Siceraria fruits (CFMLS) extract.

Table 3. $\mathrm{R}_{\mathrm{f}}$ values and percentage area of the peaks showing separated phytoconstituents in HPTLC chromatogram of acetone fraction of methanolic extract of $L$. Siceraria fruits

\begin{tabular}{|c|c|c|c|c|c|c|}
\hline \multirow[t]{2}{*}{$\begin{array}{l}\text { Peak } \\
\text { No. }\end{array}$} & \multicolumn{2}{|c|}{$\begin{array}{l}\text { Track } 1 \\
5 \mu \mathrm{l} \mathrm{CFMLS}\end{array}$} & \multicolumn{2}{|c|}{$\begin{array}{l}\text { Track } 2 \\
10 \mu \mathrm{l} \mathrm{CFMLS}\end{array}$} & \multicolumn{2}{|c|}{$\begin{array}{l}\text { Track } 3 \\
20 \mu \mathrm{l} \mathrm{CFMLS}\end{array}$} \\
\hline & $\mathbf{R}_{\mathrm{f}}$ & Area \% & $\mathbf{R}_{\mathrm{f}}$ & Area \% & $\mathbf{R}_{\mathrm{f}}$ & Area \% \\
\hline 1 & -0.03 & 0.35 & -0.03 & 0.27 & -0.03 & 0.28 \\
\hline 2 & 0.04 & 7.30 & 0.04 & 9.32 & 0.04 & 11.89 \\
\hline 3 & 0.45 & 1.5 & 0.07 & 1.06 & 0.07 & 1.53 \\
\hline 4 & 0.52 & 48.28 & 0.21 & 0.67 & 0.11 & 0.71 \\
\hline 5 & 0.64 & 5.83 & 0.45 & 1.51 & 0.36 & 0.54 \\
\hline 6 & 0.70 & 9.30 & 0.52 & 53.67 & 0.37 & 1.03 \\
\hline 7 & 0.81 & 11.2 & 0.64 & 5.19 & 0.47 & 0.82 \\
\hline 8 & 0.90 & 16.15 & 0.71 & 8.00 & 0.56 & 53.81 \\
\hline 9 & ---- & ---- & 0.82 & 9.60 & 0.67 & 4.06 \\
\hline 10 & ---- & ---- & 0.90 & 6.07 & 0.73 & 5.60 \\
\hline 11 & ---- & ---- & 0.94 & 4.35 & 0.84 & 5.18 \\
\hline 12 & ---- & ---- & ---- & ---- & 0.93 & 14.55 \\
\hline
\end{tabular}

ative activity of drugs under investigation. It is known that sleep prolongation is mediated by serotonin, dopamine, GABA, opioid, and GABA-BDZ receptors complex. ${ }^{32,33}$ Therefore, it can be supposed that CFMLS may prolong thiopental-induced sedation by acting on any of the above mentioned receptors.

Moreover, the spontaneous locomotor activity and rotarod performance (skeletal muscle relaxation) are regulated by multiple neurotransmitter systems, like acetylcholine (ACh), dopamine, serotonin, GABA, opioid, and noradrenaline. ${ }^{34,35}$ The present study showed that CFMLS significantly inhibited locomotor activity and rotarod performance in a dose-dependent manner. Therefore, it can be concluded that CFMLS might have developed inhibitory effects on locomotor activity and rotarod performance by acting on the dual receptor complex of GABA and opioid receptors.

Furthermore, for the screening of anticonvulsant action, PTZ and MES models were assessed. ${ }^{36}$ PTZ test is recognized as an authentic model for human generalized myoclonic seizures and also for absence of seizures. It shows this action by interaction to t-butyl-bicyclo-phosphorothionate site of the $\mathrm{GABA}_{\mathrm{A}}$ receptor. $\mathrm{PTZ}$ is a blocker of choice for the $\mathrm{GABA}_{\mathrm{A}}$ receptor chloride ionophore complex. ${ }^{37} \mathrm{It}$ produces convulsions by affecting adenosinergic, GABAergic, or glutamatergic systems. ${ }^{38}$ After inducing seizures, PTZ causes significant reduction in the levels of cysteine, glutathione disulfide, and thiols, while raising the levels of protein disulfides and protein carbonyl, in the cerebral cortex region of mice. ${ }^{39}$ The results of our study reported that CFMLS at the doses of 100, 200, and $400 \mathrm{mg} / \mathrm{kg}$, p.o. significantly reduced onset of myoclonic seizures in mice.

Similarly, MES test is also a well-recognized model to assess tonic-clonic seizures. In the test, tonic hind limb seizures are induced by bilateral corneal or transauricular electrical stimulation is believed to evaluate potential of anticonvulsant drug against generalized tonic-clonic seizures. ${ }^{40}$ In our study, CFMLS at doses of 100, 200, and 400 $\mathrm{mg} / \mathrm{kg}$, p.o. significantly decreased the duration of HLTE phase and protected the animals.

Pathophysiology of the epilepsy suggests that the drugs inhibit the PTZ-induced seizures, which increase GAB$A_{A}$ receptor-mediated inhibitory neurotransmission e.g., BDZ. ${ }^{41}$ Moreover, activation of N-methyl-D-aspartate (NMDA) receptor appears to be involved in the initiation and generalization of the PTZ induced seizures. ${ }^{42}$ Accordingly, the drugs that block glutamatergic excitation mediated by NMDA receptor can show anticonvulsant activity against PTZ-induced seizures. ${ }^{42}$ By considering all these reports, it can be assumed that the antiepileptic potential of CFMLS may be due to its action on GABA, NMDA, or 
glutamatergic neurotransmission.

Additionally, through the brain imaging study, it has been proved that the consumption of flavonoid and sterol-rich foods enhances the cortical and peripheral blood flow in brain, and so elevates and maintains the cerebro-vascular functions and neurogenesis process. ${ }^{43}$

\section{CONCLUSIONS}

Traditional herbs have been constantly used for prophylaxis and treatment of a number of disorders and ailments all over the humanity. In recent times, the plant drug discovery is alleged as a leading and thirsty area of interest for the investigators by considering the multidisciplinary benefits of herbs. Moreover, the investigations of herbs for neuropharmacological screening have generated a prospect to develop novel and safe herbal remedies for the management of neuropsychological disorders. The findings of the present study precisely demonstrate that Lagenaria sicerar$i a$ fruits and their bioactive phytocompounds exhibit neuroprotective potential.

\section{Acknowledgements}

We are obliged to the Head of the Department of Pharmaceutical Sciences, Saurashtra University, Rajkot, Gujarat, India, for providing the laboratory facilities during the entire course of this study. Special thanks to Dr Sumita Dasgupta, Dept. of Botany, Bhagwan Mahavir College of Science and Technology, Surat, for identification and authentication of the plant. We are extremely thankful to Mrs Jalpa Sanandiya, Asst. Prof., Department of Pharmaceutical Sciences, Saurashtra University, Rajkot, Gujarat, India, for her kind help in HPTLC analysis.

\section{Conflict of interest}

The authors declare that they have no conflict of interest.

\section{Authors' contribution}

S.P. planned the study and supervised throughout the experimental investigations; R.P. carried out the entire study; M.K. helped in the preparation and drafting of the paper manuscript.

\section{REFERENCES}

1. World Health Organization. WHO Director-General Unveils New Global Strategies for Mental Health. Press Release WHO/99-67. Geneva, Switzerland; 1999.

2. Mora S, Nillian R, Lungenstrassb $\mathrm{H}$, et al. The hydroalcoholic extract of Salvia elegans induces anxiolytic and antidepressant like effects in rats. J Ethnopharmacol 2006; 106:76-81.

3. Zhang ZJ. Therapeutic effects of herbal extracts and constituents in animal models of psychiatric disorders. Life Sci 2006; 75:1659-99.

4. Rahman ASH. Bottle Gourd (Lagenaria siceraria) - a vegetable for good health. Nat Prod Rad 2003; 2(5):249-50.

5. Shinrajan VV, Balachandra I. Ayurvedic drugs and their plant source. New Delhi, India: Oxford and IBH publishing; 1996:176-7.

6. Kirtikar KR. Indian medicinal plants. Dehradun, India; Oriental Enterprises: 2012:722-23.

7. Baranowska MK, Cisowski W. High performance liquid chromatographic determination of flavone $\mathrm{C}$-glycosides in some species of the Cucurbitaceae family. J Chromatogr 1994; 675:240-3.

8. Shirwaikar A, Sreenivasan KK. Chemical investigation and antihepatotoxic activity of the fruits of Lagenaria siceraria. Indian J Pharm Sci 1996; 58(5):197-202.

9. Duke JA. Handbook of phytochemical and constituents of grass herbs and other economic plants. Boco, Raton: CrC press; 1999:98-119.

10. Khandelwal KR. Preliminary phytochemical screening. In: Practical Pharmacognosy, 6th ed., Nirali Prakashan, Pune; 2006:149-53.

11. Harborne JB. Phytochemical methods: A guide to modern techniques of Plant Analysis, $3^{\text {rd }}$ ed., London: Chapman and Hall; 1998:129-38.

12. Organisation for Economic Co-operation and Development (OECD). Guidance Document on Acute Oral Toxicity, Environmental Health and Safety Monograph Series on Testing and Assessment; 2000:24.

13. Emamghoreishi M, Khasaki M, Aazam MF. Coriandrum sativum: Evaluation of its anxiolytic effect in the elevated plus-maze. J Ethnopharmacol 2005; 96:365-37.

14. Turner SA. Depressants of CNS. Screening procedures in pharmacology. New York: Academic Press; 1972:78.

15. Porsolt RD, Anton G, Blavet N, et al. Behavioral despair in rats: A new model sensitive to antidepressant treatments. Eur J Pharmacol 1978; 47:379-91.

16. Bhattamisra SK, Khanna VK, Agrawal AK, et al. Antidepressant activity of standardized extract of Marsiela minuta Linn. J Ethnopharmacol 2008; 117:51-7.

17. Sukma M, Chaiyo C, Murakami Y, et al. CNS inhibitory effects of barakol, a constituent of Cassia siamia Lamk. J Ethnopharmacol 2002; 83:87-94.

18. Ibarrola MC, Ibarrola DA, Montalbetti $\mathrm{Y}$, et al. The anxiolytic-like effects of Aloysia polystachya (Griseb.) Moldenke (Verbenaceae) in mice. J Ethnopharmacol 2006; 105:400-08.

19. Fisher RS. Animal models of the epilepsies. Brain Res Rev 1989; 14(3):245-78.

20. Sayyah M, Moaied S, Kamalinejad M. Anticonvulsant activity of Heracleum persicum seed. J Ethnopharmacol 2005; 98:209-11.

21. Sanja SD, Sheth NR, Patel NK, et al. Characterization and evaluation of antioxidant activity of Portulaca oleracea L. Int J Pharm Pharm Sci 2009; 1:74-84

22. Hogg S. A review of the validity and variability of the elevated plus maze as an animal model of anxiety. Pharmacol Biochem Behav 1996; 54:21-30.

23. Rodgers RJ, Cao BJ, Dalvi A, et al. Animal models of anxiety: An ethological perspective. Braz J Med Biol Res 1997; 30:289-304.

24. Dawson GR, Tricklebank MD. Use of the elevated plus maze in the search for novel anxiolytic agents. Trends Pharmacol Sci 1995; 16:33-6.

25. Pellow S, File SE. Anxiolytic and anxiogenic drug effects on explor- 
atory activity in an elevated plus-maze: A novel test of anxiety in the rat. Pharmacol Biochem Behav 1986; 24:525-29.

26. Emamghoreishi M, Khasaki M, Aazam MF. Coriandrum sativum: Evaluation of its anxiolytic effect in the elevated plus-maze. J Ethnopharmacol 2005; 96:365-70.

27. Zwanzger P, Rupprecht R. Selective GABAergic treatment for panic? Investigations in experimental panic induction and panic disorder. J Psychiatry Neurosci 2005; 30:167-75.

28. Matthews K, Christmas D, Swan J, et al. Animal models of depression: Navigating through the clinical fog. Neurosci Biobehav Rev 2005; 29:503-13.

29. Naughton M, Mulrooney JB, Leonard BE. A review of the role of serotonin receptors in psychiatric disorders. Hum Psychopharmacol 2000; 15:397-415.

30. Deakin JFW. Role of serotogenic system in escape, avoidance and other behaviors. In: Cooper SJ. Theory in Psychopharmacology. London: Academic Press; 1983:149-93.

31. Lloyd KG, Zivkovic B, Scatton B, et al. The GABAergic hypothesis of depression. Prog Neuropsychopharmacol Biol Psychiatry 1989; 13:341-51.

32. Ajayi AA, Ukponmwan OE. Evidence of angiotensin II and endogenous opioid modulation of novelty-induced rearing in the rat. Afr J Med Med Sci 1994; 23:287-90.

33. Hellion B, Ibarrola MC, Ibarrola DA, et al. Acute toxicity and general pharmacological effect on central nervous system of the crude rhizome extract of Kyllinga brevifolia Rottb. J Ethnopharmacol 1990; 66:271-76.

34. Garrett KM, Basmadjian G, Khan IA, et al. Extract of Kava (Piper methysticum) induced acute anxiolytic-like behavioural changes in mice.
Psychopharmacol (Berl) 2003; 170(1):33-41.

35. Karczmar AG. Brief presentation of the story and present status of the studies of the vertebrate cholinergic system. Neuropsychopharmacol 1993; 9:181-99.

36. Loscher W, Schmidt D. Which animal models should be used in the search for new antiepileptic drugs? A proposal based on experimental and clinical considerations. Epilepsy Res 1988; 2:145-81.

37. Velisek L, Kubova H, Pohl M, et al. Pentylenetetrazol-induced seizures in rats: an ontogenetic study. Naunyn Schmiedebergs Arch Pharmacol 1992; 346(5):588-91.

38. Diehl RG, Smialowski A, Gotwo T, et al. Development and persistence of kindled seizures after repeated injections of pentylenetetrazol in rats and guinea pigs. Epilepsia 1984; 25(4):506-10.

39. Patsoukis N, Zervoudakis G, Panagopoulos NT, et al. Thiol redox state (TRS) and oxidative stress in the mouse hippocampus after pentylenetetrazol-induced epileptic seizure. Neurosci Lett 2004; 357(2):83-6.

40. Barton ME, Peters SC, Shannon HE. Comparison of the effect of glutamate receptor modulators in the $6 \mathrm{~Hz}$ and maximal electroshock seizure models. Epilepsy Res 2003; 56(1):17-26.

41. Macdonald RL, Kelly KM. Antiepileptic drugs mechanisms of action. Epilepsia 1995; 36:S2-S12.

42. Velisek L, Kusa R, Kulovana M, et al. Excitatory amino acid antagonists and pentylenetetrazole-induced seizures during ontogenesis. The effects of 2-amino-7-phosphonoheptanoate. Life Sci 1990; 46:1349-57.

43. Nassiri-Asl M, Mortazavi SR, Samiee-Rad F, et al. The effects of rutin on the development of pentylenetetrazole kindling and memory retrieval in rats. Epilepsy Behav 2010; 18(1-2):0-53.

\title{
Нейрофрармакологическая оценка и HPTLC профиль обогащённой фритосоединением хлорофрормной фрракции метанольного экстракта Lagenaria Siceraria (Molina) Standley Fruits - мощного азиатского овощного лекарственного растения
}

\author{
Сачин Пармар ${ }^{1}$, Ракеш Праджапати ${ }^{2}$, Маниша Калариас ${ }^{3}$ \\ ${ }^{1}$ Кафедра фармацевтических наук, Университет „Саураштра“, Раджкот, Индия \\ ${ }^{2}$ Кафедра фармакогнозии, Фармацевтический колледж „Бхагван Махавир“, Сурат, Индия \\ ${ }^{3}$ Кафедра фармакогнозии, Государственный фармацевтический колледж „Б.К. Моди“, Раджкот, Индия
}

Адрес для корреспонденции: Сачин Пармар, Кафедра фармацевтических наук, Университет „Саураштра“, Раджкот, Индия; Е-таil: parmarsachin@rediffmail.com

Дата получения: 9 октября 2020 Дата приемки: 13 января 2021 Дата публикации: 28 февраля 2022

Образец цитирования: Parmar S, Prajapati R, Kalaria M. Neuropharmacological evaluation and HPTLC fingerprint profile of phytocompound-enriched chloroform fraction of methanolic extract of Lagenaria siceraria (Molina) Standley fruits - a potent Asian ethno-medicinal vegetable plant. Folia Med (Plovdiv) 2022;64(1):84-95. doi: 10.3897/folmed.64.e59492. 


\section{Резюме}

Введение: Lagenaria siceraria (Molina) Standley (тыква) - традиционное овощное растение, более известное как тыква и лаука (Хинди). Это ползучее растение, характеризующееся рядом лечебных свойств. Традиционно плоды Lagenaria siceraria (LS) использовались из-за их кардиопротекторного, гепатопротекторного, мочегонного и слабительного действия, но имеется очень мало доступных научных данных о его нейропротекторном потенциале.

Цели: Настоящее исследование направлено на оценку нейрофармакологического профиля обогащённой стеролами хлороформной фракции метанольного экстракта плодов Lagenaria siceraria в экспериментальных моделях на животных.

Материалы и методы: Проведён нейрофармакологический скрининг на конкретной животной модели. Взрослых самцов крыс-альбиносов линии Wistar подвергали тестам на поведенческое отчаяние и тесту в приподнятом крестообразном лабиринте.

Тиопентал-индуцированную седацию, двигательную активность и тест „rota rod“ проводили на мышах-альбиносах породы Swiss. Индуцированные пентилентетразолом судороги и судороги, вызванные максимальным электрошоком, были выполнены на мышах-альбиносах породы Swiss с использованием той же модели для оценки противоэпилептического потенциала.

Результаты: Результаты исследования показали, что анксиолитическая активность хлороформной фракции, обогащённой фитонутриентами метанольного экстракта плодов Lagenaria siceraria (100, 200 и 400 мг/кг перорально), характеризовался увеличением времени пребывания и увеличением количества входов в открытые ответвления прототипа приподнятого крестообразного лабиринта. по сравнению с контрольной группой ( $p<0.001)$. Фракция хлороформа (100-400 мг/кг, п.о.) показала дозозависимое достоверное сокращение продолжительности иммобилизации $(p<0.001)$ в поведенческом тесте отчаяния. Точно так же фракция хлороформа показала значительное снижение координации движений $(p<0.001)$ и удлинение времени сна, вызванного тиопенталом $(p<0.001)$ во время исследований на животных. Кроме того, испытуемая фракция значительно увеличивала ( $p<0.001)$ возникновение миоклонических судорог в модели судорог, индуцированных пентиленттразолом, а также в модели судорог, индуцированных максимальным электрошоком, при всех трёх выбранных дозах. Интересно, что фракция хлороформа не вызывала явной двигательной дисфункции или каких-либо дополнительных пирамидных симптомов ни у одной из моделей животных во время фармакологического скрининга.

Предварительный фитохимический скрининг фракции показал наличие сапонинов, фитостеролов, терпеноидов, жиров и следов полифенольных составляющих. Также был проведен анализ HPTLC.

Заключение: Это первое исследование нейропротекторного потенциала плодов Lagenaria siceraria путём выявления анксиолитической, антидепрессивной, седативной и противоэпилептической активности, что подтверждает традиционные утверждения. Будущие исследования будут сосредоточены на выделении биоактивных фитонутриентов и их точных механизмов, участвующих в нейрозащитной активности.

\section{Ключевые слова}

поведенческий тест отчаяния, тест приподнятого крестообразного лабиринта, максимальные судороги, индуцированные электрошоком, судороги, индуцированные пентилентетразолом, фитохимический скрининг, тест „rota rod“, тиопентал-индуцированная седация 